\title{
Estimated Agricultural Pesticide Use for Southeast Stream- Quality Assessment, 2014
}

Open-File Report 2015-1224

Version 2.1, July 2016 



\section{Estimated Agricultural Pesticide Use for Southeast Stream-Quality Assessment, 2014}

By Nancy T. Baker

Open-File Report 2015-1224

Version 2.1, July 2016 


\title{
U.S. Department of the Interior SALLY JEWELL, Secretary
}

\section{U.S. Geological Survey Suzette M. Kimball, Director}

\author{
U.S. Geological Survey, Reston, Virginia \\ First release: December 1, 2015 \\ Revised: December 14, 2015 (ver. 2.0) \\ Revised: July 2016 (ver. 2.1)
}

For more information on the USGS - the Federal source for science about the Earth, its natural and living resources, natural hazards, and the environment—visit http://www.usgs.gov or call 1-888-ASK-USGS.

For an overview of USGS information products, including maps, imagery, and publications, visit http://www.usgs.gov/pubprod/.

Any use of trade, firm, or product names is for descriptive purposes only and does not imply endorsement by the U.S. Government.

Although this information product, for the most part, is in the public domain, it also may contain copyrighted materials as noted in the text. Permission to reproduce copyrighted items must be secured from the copyright owner.

Suggested citation:

Baker, N.T., 2016, Estimated agricultural pesticide use for Southeast Stream-Quality Assessment, 2014 (ver. 2.1, July 2016): U.S. Geological Survey Open-File Report 2015-1224, 5 p., http://dx.doi.org/10.3133/ofr20151224.

ISSN 2331-1258 (online) 


\section{Contents}

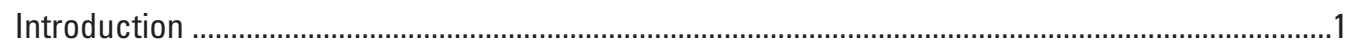

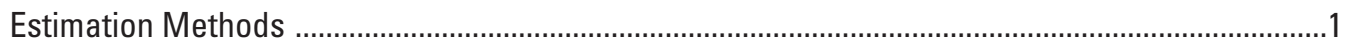

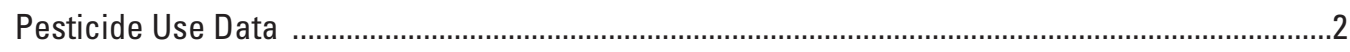

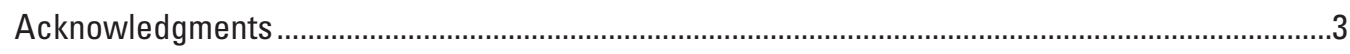

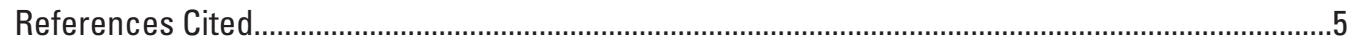

\section{Figure}

1. Location of Southeast Stream-Quality Assessment watersheds .......................................

\section{Tables}

1. Estimated pesticide use (EPest)-high and EPest-low estimates, by county, for the southeastern United States, 2014 (available at http://pubs.usgs.gov/ofr/20151224/) ........3

2. Estimated pesticide use (EPest)-high and EPest-low estimates, by watershed, for the southeastern United States, 2014 (available at http://pubs.usgs.gov/ofr/20151224/) .3

3. Southeast Stream-Quality Assessment watershed station information (available at http://pubs.usgs.gov/ofr/20151224//............................................................................ 


\title{
Estimated Agricultural Pesticide Use for Southeast Stream-Quality Assessment, 2014
}

\author{
By Nancy T. Baker
}

\section{Introduction}

One of the goals of the U.S. Geological Survey (USGS) Southeast Stream-Quality Assessment (SESQA) is to characterize contaminants at perennial-stream sites throughout the southern Piedmont and southern Appalachian Mountains. The evaluation of pesticide inputs from agricultural sources will aid in that characterization.

Methods used for calculating county-level pesticide use documented in this report are from methods developed and described by Thelin and Stone (2013) and Baker and Stone (2015). Two methods for calculating estimated pesticide use (EPest) rates-EPest-low and EPest-high-were applied in this study to estimate a probable range in the annual amounts of pesticide used for agriculture in 2014. To calculate watershed-level estimates, county-level use was proportionally allocated to agricultural land within each watershed. Concentrations of 262 pesticide compounds were estimated and compiled for subsequent analysis by the USGS National Water Quality Assessment Program, Southeast Stream-Quality Assessment.

This report provides estimates of annual agricultural use of 262 pesticide compounds for counties and selected watersheds in parts of eight southeastern States for 2014. Estimates of county- and watershed-level annual agricultural pesticide use are provided as downloadable, tab-delimited files for both EPest-high and EPest-low.

\section{Estimation Methods}

County-level estimation methods for pesticide use, which are summarized in this report, are described in detail in Thelin and Stone (2013) and Baker and Stone (2015). Pesticide-use data compiled from proprietary surveys of farm operations located within U.S. Department of Agriculture (USDA) Crop Reporting Districts (CRDs) - a collection of contiguous counties within each state - were used to calculate pesticide use per crop acre, or an "estimated pesticide use" (EPest) rate, for each pesticide compound used in a CRD. Pesticide-use estimates at the county level were then calculated by multiplying EPest rates by harvested-crop acres for each pesticide-by-crop combination in each county. The data for annual harvested-crop acres are reported in the USDANational Agricultural Statistics 2012 Census of Agriculture (Ag Census; U.S. Department of Agriculture, 2014), and the data for each crop harvested in the CRD are reported in the 2014 County Agricultural Production Survey (CAPS; U.S. Department of Agriculture-National Agricultural Statistics Service, 2015).

Two estimates-EPest-low and EPest-high-provide a range of values of pesticide use (Thelin and Stone, 2013; Baker and Stone, 2015) where a pesticide-use rate is not available for a crop from a CRD. Both estimation methods incorporate extrapolated rates and rates reported from surveys of farmers to estimate pesticide use for counties, but EPestlow and EPest-high estimation procedures differ in how they treat situations when a CRD was surveyed and pesticide use was not reported for a particular pesticide-by-crop combination. The EPest-low estimate is zero in the CRD for pesticideby-crop combinations not listed in responses from surveyed farmers. The EPest-high estimate, which is used for counties in unsurveyed CRDs and in surveyed CRDs with missing or incomplete responses from farmers, was made by using a complex algorithm described in detail by Thelin and Stone (2013). The EPest-high estimate is based on the median of reported pesticide-by-crop use rates from surveyed farmers in neighboring CRDs and, in some cases, CRDs within the same USDA Farm Resource Region (Thelin and Stone, 2013). In some cases, EPest-low annual totals can be greater than EPesthigh totals when the EPest-low regional pesticide-by-crop rate is greater than the EPest-high rate. EPest regional pesticideby-crop rates are determined by using the median rate of a minimum of three CRDs, and, typically, EPest-high regional rates are determined from the median of a greater number of CRDs than EPest-low regional rates, and this occasionally results in a higher rate for EPest-low (Thelin and Stone, 2013). 
To calculate watershed-level estimates for pesticide use, county-level pesticide-by-crop use was first aggregated to county-level pesticide use on pasture or hay and on cultivated land. This was done because the National Land Cover Database (NLCD 2011; Homer and others, 2015), which was used to proportionally allocate county estimates to agricultural land within each watershed assigns pasture or hay to NLCD class 81 and cultivated land to NLCD class 82. The NLCD 2011 land-use raster, which has a 30-meter [m] cell size, was then combined with a 30-m cell size rasterized version (JoAnn Gronberg, U.S. Geological Survey, written commun., 2012) of the Topographically Integrated Geographic Encoding and Referencing (TIGER)/Line ${ }^{\circledR}$ shapefile of county boundaries from the 2010 U.S. Census (https://www.census.gov/geo/ maps-data/data/tiger-line.html; United States Census Bureau, 2012). Thus, the combined files result in a geospatial raster that includes NLCD class 81 and class 82 for each county (NLCD-CO) located in the SESQA study area. The aggregated pesticide by county values for NLCD 81 and NLCD 82 EPest-high and EPest-low rate was then joined by county code to NLCD-CO. To obtain the NLCD-CO per 30-m cell use rate for each pesticide, the county use was divided by the number of cells within each county and NCLD 2011 class combination (NLCD-CO-EPest). Geospatial vector data of watershed boundaries, developed for 115 SESQA stream sites (Naomi Nakagaki and Sharon Qi, U.S. Geological Survey, written commun., 2015), were then used to extract the NLCD-COEPest for each watershed. For each compound, the NLCDCO-EPest cells within each watershed were summed to obtain the total pesticide use for that compound in that watershed.

\section{Pesticide Use Data}

Estimates of annual agricultural pesticide use, by county and watershed, are provided for this report as downloadable, tab-delimited files available at http://pubs.usgs.gov/ ofr/20151224/. The results for pesticide use are considered to satisfy the quality standards relative to the purpose for which the data were collected. Although these data and associated metadata have been reviewed for accuracy and completeness and approved for release by the U.S. Geological Survey (USGS), no warranty expressed or implied is made regarding the display or utility of the data on any other system or for general or scientific purposes, nor shall the act of distribution constitute any such warranty.
County-level high and low estimates, provided for the southeastern states, are listed in table 1. The area of agricultural land (NLCD classes 81 and 82) is provided to show the relative amount of agricultural land in the county. The 16 column headings in table 1 and descriptions are listed below.

\begin{tabular}{|c|c|c|}
\hline & Heading & Description \\
\hline 1. & STATE_FIPS_CODE & $\begin{array}{l}\text { Federal Information } \\
\text { Processing Standard (FIPS) } \\
\text { code }\end{array}$ \\
\hline 2. & STATE & state name \\
\hline 3. & COUNTY_FIPS_CODE & county FIPS code \\
\hline 4. & COUNTY & county name \\
\hline 5. & STATECO_FIPS_CODE & $\begin{array}{l}\text { combined state and county } \\
\text { FIPS code }\end{array}$ \\
\hline 6. & YEAR & year \\
\hline 7. & COUNTY_AREA_KM2 & $\begin{array}{l}\text { area of the county, in square } \\
\text { kilometers }\left(\mathrm{km}^{2}\right)\end{array}$ \\
\hline 8. & LU81_KM2 & $\begin{array}{l}\text { area of NLCD class } 81 \text { land } \\
\text { use, in } \mathrm{km}^{2}\end{array}$ \\
\hline & LU82_KM2 & $\begin{array}{l}\text { area of NLCD class } 82 \text { land } \\
\text { use, in } \mathrm{km}^{2}\end{array}$ \\
\hline 10. & COMPOUND & pesticide compound name \\
\hline & EPEST_HIGH_LU81_KGS & $\begin{array}{l}\text { high estimated pesticide use } \\
\text { for NLCD class } 81 \\
\text { (pasture or hay), in } \\
\text { kilograms (kgs) }\end{array}$ \\
\hline 12. & EPEST_HIGH_LU82_KGS & $\begin{array}{l}\text { high estimated pesticide use } \\
\text { for NLCD class } 82 \text { (culti- } \\
\text { vated land), in kgs }\end{array}$ \\
\hline 13. & EPEST_HIGH_KGS & $\begin{array}{l}\text { high estimated total pesticide } \\
\text { use for classes } 81 \text { plus } 82 \\
\text { combined, in kgs }\end{array}$ \\
\hline 14. & EPEST_LOW_LU81_KGS & $\begin{array}{l}\text { low estimated pesticide use for } \\
\text { NLCD class } 81 \\
\text { (pasture or hay), in kgs }\end{array}$ \\
\hline 15. & EPEST_LOW_LU82_KGS & $\begin{array}{l}\text { low estimated pesticide use for } \\
\text { NLCD class } 82 \text { (cultivated } \\
\text { land), in } \mathrm{kgs}\end{array}$ \\
\hline 16. & EPEST_LOW_KGS & $\begin{array}{l}\text { low estimated total pesticide } \\
\text { use for classes } 81 \text { and } 82 \\
\text { combined, in kgs }\end{array}$ \\
\hline
\end{tabular}


High and low estimates of pesticide use, organized by watershed station identification number, are provided in table 2. The area of agricultural land (NLCD classes 81 and 82 ) is provided to show the relative amount of agricultural land in the watershed. The 14 column headings in table 2 and descriptions are listed below.

\begin{tabular}{|c|c|c|}
\hline & Heading & Description \\
\hline & STATION_ID & $\begin{array}{l}\text { watershed identification } \\
\text { number }\end{array}$ \\
\hline 2. & YEAR & year \\
\hline & STATION_DA_KM2 & $\begin{array}{l}\text { drainage area of the watershed, } \\
\text { in } \mathrm{km}^{2}\end{array}$ \\
\hline 4. & LU81_KM2 & $\begin{array}{l}\text { area of NLCD class } 81 \text { land } \\
\text { use, in km2 }\end{array}$ \\
\hline 5. & LU82_KM2 & $\begin{array}{l}\text { area of NLCD class } 82 \text { land } \\
\text { use, in km2 }\end{array}$ \\
\hline 6. & COMPOUND & pesticide compound name \\
\hline 7. & EPEST_HIGH_LU81_KGS & $\begin{array}{l}\text { high estimated pesticide use } \\
\text { for NLCD class } 81 \text { (pasture } \\
\text { or hay), in kgs }\end{array}$ \\
\hline 8. & EPEST_HIGH_LU82_KGS & $\begin{array}{l}\text { high estimated pesticide use } \\
\text { for NLCD class } 82 \text { (culti- } \\
\text { vated land), in kgs }\end{array}$ \\
\hline & EPEST_HIGH_KGS & $\begin{array}{l}\text { high estimated total pesticide } \\
\text { use for classes } 81 \text { plus } 82 \\
\text { combined, in kgs }\end{array}$ \\
\hline 10. & EPEST_HIGH_KGSperKM2 & $\begin{array}{l}\text { high estimated total pesticide } \\
\text { use, in } \mathrm{kgs} \text { per } \mathrm{km}^{2} \text { of land } \\
\text { in the watershed }\end{array}$ \\
\hline 11. & EPEST_LOW_LU81_KGS & $\begin{array}{l}\text { low estimated pesticide use for } \\
\text { NLCD class } 81 \text { (pasture or } \\
\text { hay), in kgs }\end{array}$ \\
\hline 12. & EPEST_LOW_LU82_KGS & $\begin{array}{l}\text { low estimated pesticide use for } \\
\text { NLCD class } 82 \text { (cultivated } \\
\text { land), in kgs }\end{array}$ \\
\hline 13. & EPEST_LOW_KGS & $\begin{array}{l}\text { low estimated total pesticide } \\
\text { use for classes } 81 \text { and } 82 \\
\text { combined, in kgs }\end{array}$ \\
\hline 14. & EPEST_LOW_KGSperKM2 & $\begin{array}{l}\text { low estimated total pesticide } \\
\text { use, in kgs per } \mathrm{km} 2 \text { of land } \\
\text { in the watershed }\end{array}$ \\
\hline
\end{tabular}

Watersheds in the southeastern United States that are part of the SESQA study area and for which pesticide use was estimated are shown in figure 1. The SESQA watershed station information is listed in table 3.

\section{Acknowledgments}

Several U.S. Geological Survey colleagues are gratefully acknowledged for assisting with various aspects of this investigation. Geospatial vector data of watershed boundaries for SESQA were provided by Naomi Nakagaki and Sharon L. Qi. Geospatial raster data of 2010 county boundaries were provided by JoAnn M. Gronberg. Technical reviews were provided by Aubrey R. Bunch and W. Fred Falls.

Table 1. Estimated pesticide use (EPest)-high and EPest-low estimates, by county, for the southeastern United States, 2014 (available at http://pubs.usgs.gov/ofr/20151224/).

Table 2. Estimated pesticide use (EPest)-high and EPest-low estimates, by watershed, for the southeastern United States, 2014 (available at http://pubs.usgs.gov/ofr/20151224/).

Table 3. Southeast Stream-Quality Assessment watershed station information (available at http://pubs.usgs.gov/ ofr/20151224/). 


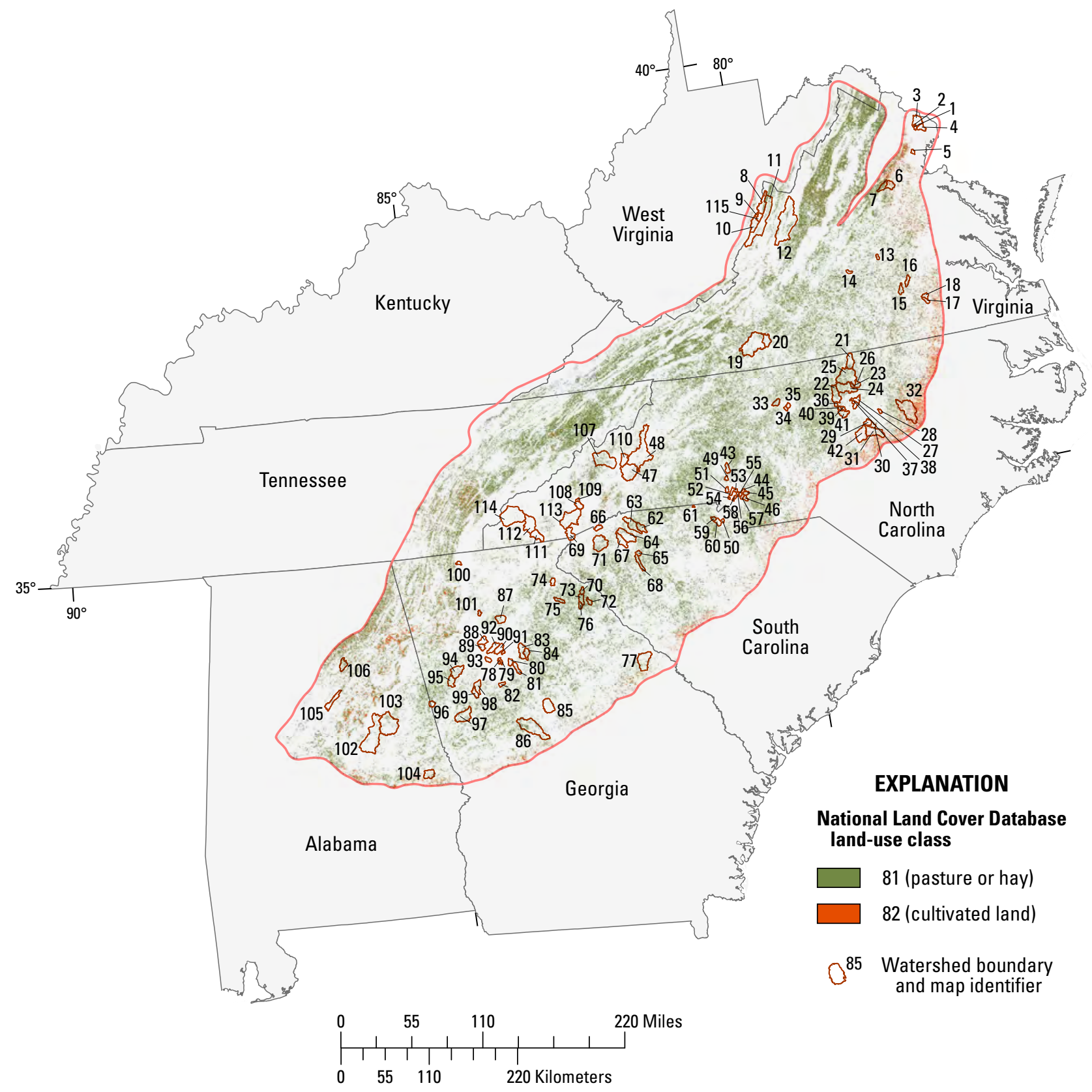

Figure 1. Location of Southeast Stream-Quality Assessment watersheds. 


\section{References Cited}

Baker, N.T., and Stone, W.W., 2015, Estimated annual agricultural pesticide use for counties of the conterminous United States, 2008-12: U.S. Geological Survey Data Series 907, 9 p., http://dx.doi.org/10.3133/ds907.

Homer, C.G., Dewitz, J.A., Yang, L., Jin, S., Danielson, P., Xian, G., Coulston, J., Herold, N.D., Wickham, J.D., and Megown, K., 2015, Completion of the 2011 National Land Cover Database for the conterminous United StatesRepresenting a decade of land cover change information: Photogrammetric Engineering and Remote Sensing, v. 81, no. 5, p. 345-354, accessed November, 2, 2014, at http://www.asprs.org/a/publications/pers/2015journals/ PERS_May_2015/HTML/index.html\#345/z.

Thelin, G.P., and Stone, W.W., 2013, Estimation of annual agricultural pesticide use for counties of the conterminous United States, 1992-2009: U.S. Geological Survey Scientific Investigations Report 2013-5009, 54 p.

U.S. Census Bureau, 2012, TIGER/Line ${ }^{\circledR}$ shapefiles and TIGER/Line ${ }^{\circledR}$ files: accessed October 15, 2015, at https://www.census.gov/geo/maps-data/data/tiger-line.html.

U.S. Department of Agriculture, 2014, 2012 Census of agriculture, United States summary and state data: U.S. Department of Agriculture, National Agricultural Statistics Service, Geographic Area Series, v. 1, pt. 51, AC-12-A-51, accessed May 2013 at http://www.agcensus. usda.gov/Publications/2012/.

U.S. Department of Agriculture, 2014, 2012 Census of agriculture, county-level data: U.S. Department of Agriculture, National Agricultural Statistics Service, v. 1, chap. 2, accessed October 15, 2015, at http://www.agcensus. usda.gov/Publications/2012/Full_Report/Volume_1,_Chapter_2_County_Level/.

U.S. Department of Agriculture-National Agricultural Statistics Service, 2015, Quick-Stats—Field crops, 2014: Washington D.C., U.S. Department of Agriculture, accessed April 2015 at http://www.nass.usda.gov/Quick_Stats/. 




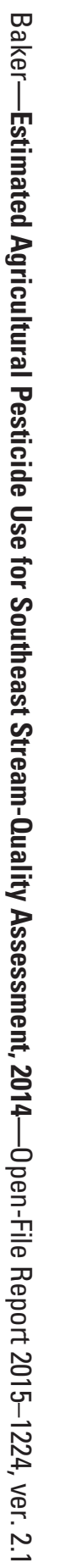

